Note

\title{
Good practice: International Honors Summer Institute on Holocaust Remembrance
}

Henmar Moesker, Carline de Boer, and Pieter Veenstra

Hanze Honours College, Hanze University of Applied Sciences Groningen, The Netherlands; h.m.moesker@pl.hanze.nl, c.a.de.boer@pl.hanze.nl,p.f.veenstra@pl.hanze.nl

Correspondence: $\underline{\text { h.m.moesker@pl.hanze.nl }}$

Received: 29 June 2018; Accepted: 4 December 2018; Published: 7 January 2019

Keywords: international, honors, summer school, Holocaust, interdisciplinary, multidisciplinary

Note to reader: honors keywords (see introductory article of this issue) in italics in the text

\section{Introduction}

Hanze University of Applied Sciences Groningen and Memorial Centre Camp Westerbork in the Netherlands have been working together for the last few years in organizing honors projects that connect lessons from the remarkable history of Camp Westerbork to issues and problems of today's society. One of the projects in this cooperation is the International Honors Summer Institute on Holocaust Remembrance, in which American and Dutch students work together in a project connecting past and present day issues in society. This summer school is open for honors students from the Dutch institutes Hanze UAS (Groningen) and Windesheim UAS (Zwolle), as well as American universities. Credits are awarded that can be applied to the student's regular program and/or honors program.

\section{Why this good practice?}

The purpose of the summer school is to further personal and social development of students by providing a project in which international cooperation, working from different perspectives, and social responsibility are key components. This is done by connecting World War II history with present day developments and their impact on modern-day society. In the past editions of the summer school, students were provided with the opportunity to collaborate with an international cohort to study Holocaust history. Students used these "lessons from the past" to examine, investigate, and critique problems in today's societies, concentrating on the theme of bystanders. The students also visited Camp Westerbork. This is a former concentration camp from the Second World War, which is now a memorial center and museum. 


\section{Target group and target group size}

The target group consists of honors students from a few Dutch colleges (Hanze and Windesheim) and American universities. A maximum of 24 students can be admitted. US students must pay a course fee of 2000 euros (that includes participation in the entire program, participation in all excursions, participation in all social activities, housing, five dinners, and a rental bike). Dutch students pay a course fee of 250 euros. Students work intensively in the summer school for approximately two and a half weeks. There are also some preparatory lectures online.

\section{Educational design (structure)}

Before the actual summer school starts, students research Holocaust history. There are online lectures, readings, and assignments. The summer school itself is a program with excursions to several Holocaust sites in the Netherlands and Germany, as well as opportunities to work on projects on location at Memorial Center Camp Westerbork. In the first editions, students worked in small groups. They created a photo exhibition and a TED Talk video about bystanders in the past and what it is to be a bystander in today's society. Each team then presented their projects. By working together in an international group, creating their own project in relation to the complex problems of today's society and the use of their initiative and creativity, honors students used their 21st century skills to the fullest.

\section{Student assessment}

At the beginning of the summer school, students formulate their own learning goals. They reflect on the realization of these learning goals in the final reflection they have to write. They also reflect on the cooperation within their group, their group results, and their own role within the group. Participants receive a certificate upon completion.

\section{Experiences}

For this program, personal reflections on the program were used to evaluate the insights and skills students developed in the program. From these reflections, it became clear that students used all kinds of 21st century skills in this summer school, like cooperation in a diverse group, creative thinking, critical thinking, and taking different perspectives into account.

The participating students not only learned a lot about the history of WWII, but they also used their imagination and creativity in the assignments, making good use of the diversity in backgrounds, skills, and subject areas in their group, to create products that can be shown to different audiences and stimulate their awareness of social issues.

In the final reflection, all participating students agreed that this summer school enhanced their personal development by stimulating their thinking about society and their role in that society. All students agreed that the diversity in the group (both in nationality and in academic background) and the discussions in their group enhanced their thinking from different perspectives and their critical thinking and creativity.

Some quotes from American students on the summer school (2017 and 2018) include: -'The Hanze Summer School on Holocaust Remembrance was an experience I will never forget. The friendships I've made, lessons I've learned, and places I've visited follow me for 
the rest of my life. From the bottom of my heart, l'm so grateful to have such an amazing opportunity to collaborate with individuals who have much to offer in insight, stories, and just overall personality. This trip fulfilled all my original goals of wanting to be culturally immersed in the Netherlands, as well as to collaborate with like-minded people who also have an interest in seeking to understand the Holocaust and the effect bystanders have to the past, present and future.'

-'The whole experience was extremely valuable in my development of speaking, critical thinking, and multitasking skills. The summer school allowed me to think for myself, be independent, but also collaborate with others.'

-'One part of this trip I'll never forget was when we talked to a Holocaust survivor in Westerbork and he recounted how his immediate family had managed to survive.'

-'I think I have accomplished each of my learning goals that I outlined at the beginning of the program. I have gained a better understanding of the events of the Holocaust and how these events can be compared to what is occurring in today's world, in particular the Syrian Refugee Crisis, which my group chose to focus on in our project.'

-'Some educators believe that the information [about the Holocaust] is too difficult to take in, hesitating to teach even older students the important details of how a single government caused the murder of millions of people. Now I believe, however, that it is our responsibility as global citizens to think critically about disasters of the past, even if it makes us uncomfortable for a while. This can help us be prepared to deal with urgent humanitarian issues today.'

-'Over the course of the past two weeks, I've learned a lot more about refugees then and now, and how not doing something can be just as bad as being a perpetrator of a genocide like the Holocaust. I also learned that it's important to evaluate your own country's role in the world, and how the history of your country can have a big impact on how other countries behave in reaction to your country. A very impactful program that used our time well.'

An additional remark on the organization of the summer school is this: American universities are very interested, but it is not easy to accomplish the program. Lack of funding for American students may be a problem, as well as schedules and logistics. Also, Dutch students have their schedules and study obligations, which can interfere.

\section{Time requirement for teachers}

This summer school requires full-time dedication from two teachers for the duration of the summer school and about 40 hours in preparation. Some of the preparation time is spent on discussing the pedagogical aspects of the summer school. Participating teachers need to give students freedom to choose and develop their projects in the summer school. An important aspect for teachers is to be able to handle the impact of the experiences in the summer school on students, since they can be very overwhelming. This is an important subject in the preparation of teachers.

Also, a student-assistant is needed to help with the social parts of the program.

\section{Tips for teachers}

In the summer school, an experienced honors teacher worked together with a representative of Memorial Center Westerbork as coaches for the participating students. In their reflections, students remarked that they appreciated the freedom and opportunity for 
creative thinking they had in working on their projects. The coaches used a didactic approach of coaching by asking questions and stimulating students to exchange their ideas.

\section{Tips for students}

In this summer school, you'll get a chance to bond with foreign students while studying the fascinating history of Camp Westerbork and several Holocaust sites in Europe. By joining, you will enhance your 21st century skills in several ways.

\section{Transfer to other programs}

Although the summer school as a whole cannot be transferred to regular programs, elements of it may be used, like letting students work in multidisciplinary groups and working with assignments that require cooperation, creative skills, and using different perspectives. Also the combination of learning on location, speaking to different people related to the subject of study, and using this input in a real life project could work well in any educational setting.

\section{References, additional information, and relation with Circle of Talent Development}

\section{Additional information}

The Summer School on Facebook:

https://www.facebook.com/pg/hanzesummerschool/posts/?ref=page internal

Website Hanze UAS:

https://www.hanze.nl/eng/education/summer-courses/hanze-summer-

school/courses/honours-summer-school-holocaust-remembrance/about-honours-summerschool-holocaust-remembrance

\section{$\underline{\text { Relation with Circle of Talent Development }}$}

In the introductory article of this issue of JEHC, the 'Circle of Talent Development' has been described. Based on interviews with forty honors students and literature about honors programs, it reflects relevant activities of students regarding the development of their talents in an honors program. The author of this note has been asked to score the good practice in relation to the activities in the Circle of Talent Development. The meaning of the scores is: + = somewhat important; $++=$ moderately important; $+++=$ very important; $-=$ not applicable or irrelevant. The scores are intended to illustrate the strengths of a good practice for the reader. 
Figure 1: Circle of Talent Development in relation with the good practice 'International Honors Summer Institute on Holocaust Remembrance' with the teacher's scores

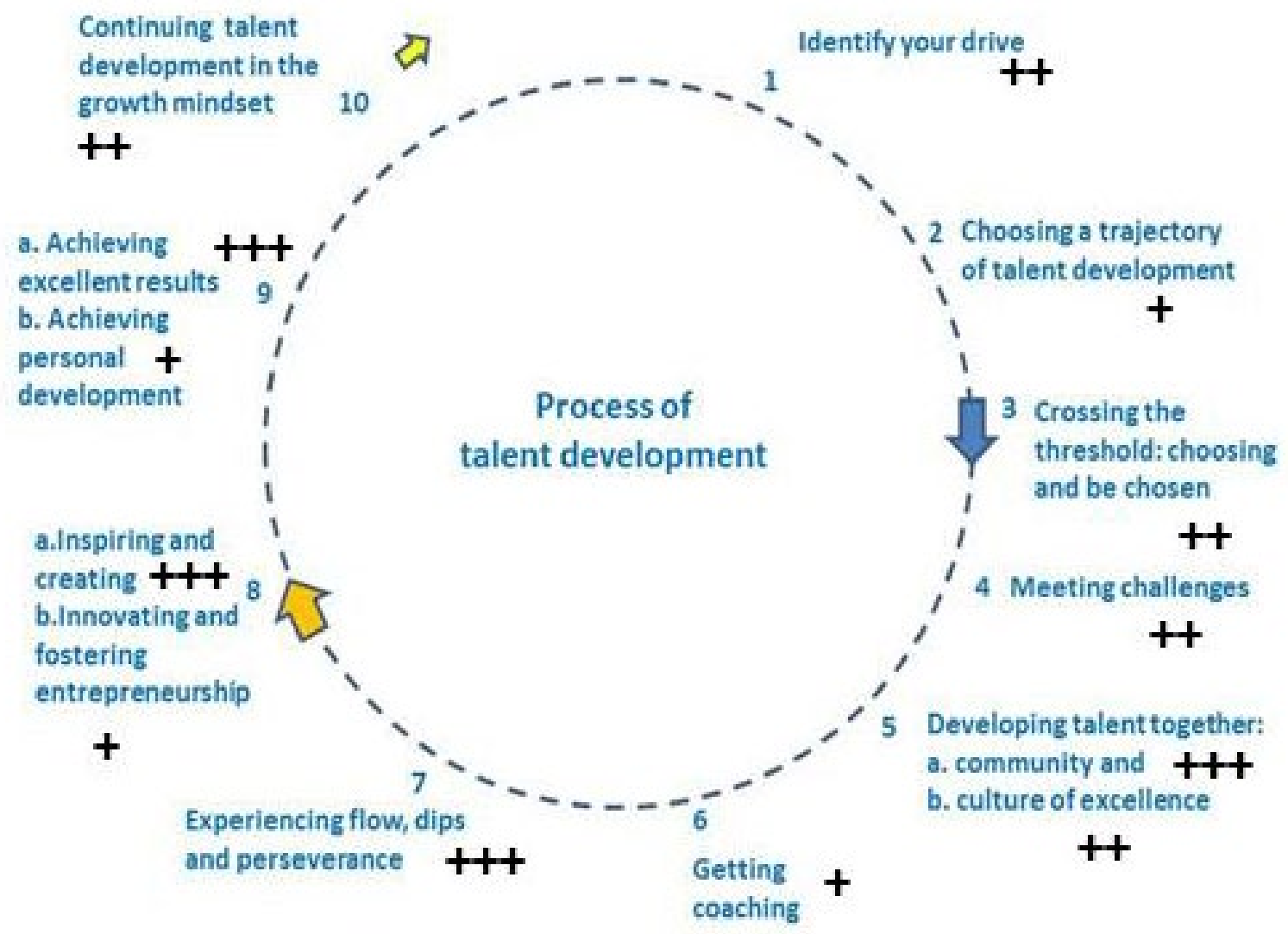

Question to the teacher: What makes this good practice attractive for other teachers? The teacher of this practice argues: 'The summer school is an intensive program with high impact. The power is in the combination of two elements: bringing together students from different backgrounds to research a topic that relates to societal problems, and asking students to use their creativity to create something to communicate their vision on these societal problems.' 